\title{
The Effect of Physical Activity on Bone Density in Military Personnel
}

\author{
Askeri Personel Kemik Yoğunluğu Üzerine Fiziksel Aktivitenin Etkisi \\ Iman Mokhtari Garakani, Farid Rezaei Moghaddam*, Kamran Azma*, Mozhgan Kamalifard**, Mehdi Kouchakali** \\ Iran University of Medical Sciences, Yaft-Abaad General Hospital, Department of Physical Therapy and Rehabilitation, Tehran, Iran \\ *Aja University of Medical Sciences, 501 Hospital, Physical Therapy and Rehabilitation Center, Tehran, Iran \\ **Negin Sanat-sabz Occupational Medicine Clinic, Occupational Medicine Specialist, Tehran, Iran \\ ${ }^{* * *}$ Ahvaz Jundishapur University of Medical Sciences, Department of Physical Therapy and Rehabilitation, Ahvaz, Iran
}

\section{Summary}

Objective: The aim of this study was to assess the effect of life style factors including physical activity, calcium intake, and smoking on bone mineral density (BMD).

Materials and Methods: From January 2012 to May 2013, calcaneal BMD of 335 male military personnel (aged between $35-55$ years) in two equal separate groups; operative (active field soldiers) and non-operative (official army staff) were evaluated with dual X-ray and laser Calscan. Information about lifestyle factors including smoking, calcium intake and physical activity were collected through a questionnaire. Operative personnel had daily regular physical activity. Operatives were compared with non-operative personnel who did not perform the regular active field training maneuvers.

Results: The mean age of participant was $44.7 \pm 0.5$ years and all were male. The rate of osteopenia and osteoporosis was lower in operative group than in non-operative group. Linear regression revealed that BMD is significantly associated with job $(p<0.001)$, age $(p<0.001)$, smoking $(p<0.01)$, calcium intake $(p<0.05)$, and years of physical activity $(p<0.001)$.

Conclusion: Based on the findings of the study, years of regular physical activity and mechanical loading were the strongest predictors of calcaneus BMD.

Keywords: Bone mineral density, calcaneus, physical activity

\section{Öz}

Amaç: Bu çalışmanın amacı, fiziksel aktivite, kalsiyum alımı ve sigara içiminin dahil olduğu yaşam biçimi faktörlerinin, kemik mineral yoğunluğu (KMY) üzerine etkisini değerlendirmektir.

Gereç ve Yöntem: Ocak 2012 - Mayıs 2013 tarihleri arasında, yaşları 35-55 arasında değişen 335 erkek askeri personel kalkaneus KMY yönünden operatif (etkin alan askerleri) ve non-operatif (resmi ordu personeli) olmak üzere iki gruba ayrıldı ve bu kişiler çift X-ray ve lazer Calscan ile değerlendirildi. Sigara içimi, kalsiyum alımı ve fiziksel aktivite de dahil olmak üzere yaşam tarzı faktörleri hakkındaki bilgi bir anket aracılığılla toplanmıştır. Operatif personel günlük düzenli fiziksel aktivite yapıyordu. Operatöre edilmiş personel, düzenli etkin saha eğitim manevrası yapmayan non-operatiflerle karşılaştırıldı.

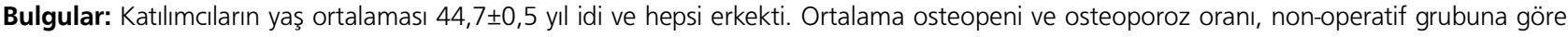
operatif gruptan daha düşüktü. Doğrusal regresyon KMY'nin önemli ölçüde iş $(p<0,001)$, yaş $(p<0,001)$, sigara içimi $(p<0,01)$, kalsiyum alımı $(p<0,05)$ ve fiziksel aktivite süresi $(y ı l ; p<0,001)$ ile ilişkili olduğunu ortaya koymuştur.

Sonuç: Çalışmanın bulgularına bağlı olarak, fiziksel aktivite süresi ve mekanik yükleme, kalkaneus KMY'nin en güçlü öngörücülerinden birisidir. Anahtar kelimeler: Kemik mineral yoğunluğu, kalkaneus, fiziksel aktivite 


\section{Introduction}

Osteoporosis is a disease characterized by low bone mass and microarchitectural deterioration of the bone tissue leading to increased bone fragility and a consequent increase in fracture risk. According to the World Health Organization (WHO) criteria, osteoporosis diagnosis is made with the bone mineral density (BMD) equal or less than 2.5 standard deviation (SD) below the average value for young healthy adults (30-40-year-old) (1). With increasing age, bone density decreases, osteoporosis rate increases and therefore fracture incidence increases. The frequency of osteoporosis in women is higher than in men. The prevalence of osteoporosis in postmenopausal women over 50 years of age is 33\% while it increase to $80 \%$ at the age 80 years (2), osteoporosis, whether primary or secondary, causes increased susceptibility of the bone to fractures. Osteoporotic fractures are a major public health problem worldwide due to their high morbidity, mortality and costs.

Dual-energy X-ray absorptiometry (DXA) is the gold standard modality for diagnosis of osteoporosis and prediction of fractures (3). DXA is expensive, non-portable, requires specialized training and is usually limited to secondary-care hospitals.

One-year mortality following hip fracture is estimated to be $14 \%$ to $58 \%(4-6)$. The first year after a hip fracture is the most critical time. Women with a hip fracture have a 5 -fold increase while men have an 8-fold increase in relative likelihood of death within the first three months of fracture compared to age- and sex-matched controls (7).

Early detection of those at highest risk for osteoporotic fractures is of clinical relevance to prevent such fractures and their potential consequences for both patients and the health care system.

DXA of the axial skeleton is the most widely used method, but some studies have shown that BMD in the peripheral sites, such as the calcaneus and the radius, can also be used to assess fracture risk, with similar predictive power at hip and spine $(8,9)$.

More than $90 \%$ of calcaneus is consisted from trabecular bone that has a high metabolic turnover rate (10).

The peripheral DXA or the same dual X-ray and laser (DXL) technique uses two $X$-ray energies in combination with laser for measurements of the bone mass and thickness of the heel in order to determine the bone mineral, the lean tissue and the adipose tissue more accurately.

It has generally lower cost, more compact size, shorter scanning time, and lower radiation exposure; therefore, it can be used more easily and widely anywhere in the world to diagnosis low bone mass (11).

Different factors such as smoking, physical inactivity, and caffeine intake and alcohol consumption have been known as risk factor for osteoporosis $(12,13)$.

The aim of this study was to assess the effect of lifestyle factors including physical activity, job, calcium intake, and smoking on peripheral BMD.

\section{Materials and Methods}

This cross-sectional comparative study was conducted on male military personnel from Jan 2012 to May 2013 in AJA University of Medical Sciences, Tehran, Iran. Participants were selected by cluster random sampling from six Garrisons and military staff departments in Tehran (about 60 cases from each center).

For this study, 335 healthy males without any bone or joint disease were selected from military personnel aged 35-55 years. Individuals with rheumatic and endocrine disorders, renal and liver failure, cancer and addiction, a lifetime history of 3-month complete bed rest or history of hospital admission in the recent two weeks, those taking calcium or low dose vitamin D in recent two weeks as well as those taking high dose vitamin D or levothyroxine in the past six months were excluded from the study. Patients with any defect in heel area such as ulcer or amputation, those with a very low BMD or sever osteoporosis (osteoporosis with a fragility fracture) and those refused to participate were excluded as well.

Two groups of study were selected from operative military personnel (168 active field soldiers) and non-operative personnel (167 military official staff).

Operative group were including military personnel with regular exercise and training program including marching at least twice a week, walking at least 30 minutes daily and army special field operation at least 4 times a year.

Non-operative group included military personnel without any regular active training program.

Information about lifestyle factors including smoking, calcium intake and physical activity were collected through a questionnaire designed by the investigator.

Calcaneal BMD of all participants was measured with DXL Calscan (Calscan ${ }^{\circledR}$; Demetech $A B$; Taby, Sweden) by a skillful and trained operator. Trabecular bones like calcaneus due to their high metabolism are good sites for assessing the bone metabolic state, and its subsequent effect on bone fragility. Studies showed that the calcaneus was a good site for the prediction of lumbar spine fractures.

The DXL Calscan (Figure 1) for estimation of the heel BMD uses combination of the conventional DXA technique and

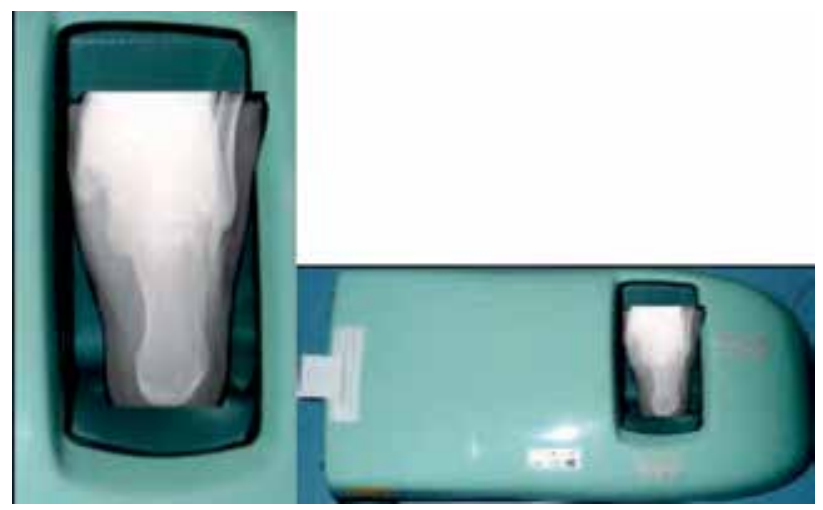

Figure 1. Dual X-ray and laser Calscan unit 
a laser measurement of the heel. The laser measurement enables patient-specific calculation to assess the impact from soft and adipose tissues. By comparing the estimated BMD to a physician-selected reference database, a potentially more accurate T-score is calculated (compared to DXA alone). This provides an estimate of osteoporotic fracture risk.

Ethics committee at AJA University of Medical Sciences approved the study protocol and all participants gave informed written consent before enrollment.

\section{Statistical Analysis}

The T-score values were used as the basis of the analysis. According to the WHO criteria, T-score -2.5 and below was defined as osteoporosis, T-score between -1.0 and -2.5 as osteopenia and T -score -1.0 and above as normal BMD.

SPSS version 11.5 for Windows was used for the statistical analysis. Data are presented as mean and SD for numerical data and number and percentage for categorical data. Numerical data were compared using independent sample t-test and categorical data were compared between the two groups by application of chi-square test. To remove confounders logistic regression model was used. P value less than 0.05 was considered as significance level.

\section{Results}

In this comparative study, BMD of 335 military personnel with mean age of $44.7 \pm 0.5$ (35-55 years) was evaluated. All participants were male. Demographic characteristics of two study groups are shown in Table 1.

Among all participants, 219 individuals (65.4\%) had normal BMD, 114 (34\%) had osteopenia and only two (0.6\%) individuals had osteoporosis that both were in non-operative group. Also, 177 persons (52.83\%) had normal body mass index (BMI), 74 participants (22.1\%) were smokers, 298 (89\%) had sunlight exposure, 84 (25.1\%) had physical activity and 252 (75.2\%) had sufficient dairy intake.

There was a significant association between osteopenia and age, BMl and physical activity ( $p<0.05$ for all associations) (Table 2). However, there was no significant association between osteopenia and smoking as well as sunlight exposure $(p=0.19$ and $p=0.87$, respectively) (Table 2 ).

Linear regression revealed that BMD is significantly associated with job $(p<0.001)$, age $(p<0.001)$, smoking $(p<0.01)$, calcium intake $(p<0.05)$, and years of physical activity $(p<0.001)$.

\section{Discussion}

This study showed lower prevalence of osteopenia and osteoporosis in operative military personnel. Operative group had significantly higher dietary intake and physical activity and lower BMI compared to non-operative group.

The DXL technique uses two X-ray energies in combination with laser measurement of the object thickness in order to determine three tissue components with a high accuracy.

It has been shown that calcaneus can predict the risk of

\section{Table 1. Demographic characteristics of all participants in two study groups}

\begin{tabular}{|c|c|c|c|}
\hline Variable & Operative personnel $n=168$ & Non-operative personnel $n=167$ & p value \\
\hline Age (year) (mean \pm SD) & $41.6 \pm 0.6$ & $43.5 \pm 0.6$ & $p<0.001$ \\
\hline $\mathrm{BMI}, \mathrm{kg} / \mathrm{m}^{2}($ mean $\pm \mathrm{SD})$ & $26.5 \pm 0.5$ & $27.6 \pm 2.9$ & $p<0.001$ \\
\hline T-score, $($ mean \pm SD) & $-0.32 \pm 0.1$ & $-1.04 \pm 0.1$ & $p<0.001$ \\
\hline Osteopenia, n (\%) & $18(10.7)$ & $96(57.5)$ & $p<0.001$ \\
\hline Osteoporosis, n (\%) & $0(0.0)$ & $2(1.2)$ & $p<0.001$ \\
\hline
\end{tabular}

Table 2. Relationship between different factors and prevalence of osteopenia and osteoporosis

\begin{tabular}{|c|c|c|c|}
\hline Factor & Prevalence of osteopenia $n(\%)$ & Prevalence of osteoporosis n (\%) & p value \\
\hline $\begin{array}{l}\text { Smoking } \\
\text { Yes } \\
\text { No }\end{array}$ & $\begin{array}{l}30(40.54) \\
84(32.18) \\
\end{array}$ & $\begin{array}{l}1(1.35) \\
1(0.38) \\
\end{array}$ & 0.19 \\
\hline $\begin{array}{l}\text { BMI } \\
\text { Normal } \\
\text { Higher than normal }\end{array}$ & $\begin{array}{l}51(28.81) \\
63(39.87) \\
\end{array}$ & $\begin{array}{l}1(0.56) \\
1(0.63)\end{array}$ & $0.03^{*}$ \\
\hline $\begin{array}{l}\text { Sunlight } \\
\text { Yes } \\
\text { No }\end{array}$ & $\begin{array}{l}101(33.89) \\
13(35.13)\end{array}$ & $2(5.40)$ & 0.87 \\
\hline $\begin{array}{l}\text { Physical activity } \\
\text { Yes } \\
\text { No }\end{array}$ & $\begin{array}{l}18(21.42) \\
98(39.04)\end{array}$ & - & $0.003^{*}$ \\
\hline
\end{tabular}


fractures in the hip and lumbar spine. The value of calcaneus BMD for prediction of vertebral fracture is comparable to those of the spine while higher than that for the forearm and hip (14). The main advantage of peripheral device (Calscan) over conventional DXA is that it is much cheaper, portable, requires no trained operator and can normally handle about 70 to 80 patients a day versus 15-20 persons for axial DXA method.

Forogh et al. (15) in 2005 compared the efficacy of DXA and DXL in measuring BMD. They evaluated BMD in 475 middleaged women with axial DXA and DXL Calscan simultaneously and considered DXA as gold standard method. Their study showed that there is a good correlation between axial DXA and DXL Calscan measurements.

In another study, Salimzadeh et al. (16) evaluated BMD in 268 postmenopausal women with both axial DXA and DXL Calscan. They found moderate agreement between the two methods for diagnosis of osteoporosis. They concluded that DXL is not a good substitute for DXA method, but it is a good screening method for detection osteoporosis.

Physical activity specially weight bearing exercise increases bone strength because it puts stress on the bone (17). In a study by Pettersson et al. (18) calcaneal BMD was measured by DXA in 2.384 young males from those attending the mandatory tests for selection to compulsory military service. They concluded that physical activity during growth is the most potent predictor of peak calcaneal BMD in young men.

Nilsson et al. (19), evaluated the association between physical activity early in life and BMD in 498 old age mean and found that competitive sports early in life (10-35 years) have been associated with BMD in elderly and it independently predicted BMD at elderly (75-year old). A similar study again by Nilsson et al. (20) in 597 old men showed that exercise during growth and young adulthood independently associated with cortical bone size and strength.

Nilsson et al. (21) also evaluated the relation between physical activity and BMD (using DXA) in 833 young men in a 5-years longitudinal study. They found that increased physical activity is related to $\mathrm{BMD}$ and cortical bone size and exercise is important in achievement of optimal peak bone mass in young men.

In a study performed on 755 young men in the United States Military Academy, calcanenal BMD was measured by peripheral DXA. This study revealed that race, body size, dietary intake and duration of weekly exercise were important determinants of BMD (22) and bone size as it was shown in Liberato et al. (23) study.

All above-mentioned findings are in line of our study and confirm our study findings.

Lack of assessment of physical activity type is limitation of this study.

\section{Conclusions}

This study showed that a long-term regular exercise program and sufficient dairy intake increase BMD and reduce osteopenia and osteoporosis in young men. Also, years of regular physical activity and mechanical loading are the strongest predictors of calcaneal BMD as well as job, age and smoking.

\section{Ethics}

Ethics Committee Approval: Ethics committee at AJA University of Medical Sciences approved the study protocol, Informed Consent: All participants gave informed written consent before enrollment.

Peer-review: Internally peer-reviewed.

\section{Authorship Contributions}

Concept: Iman Mokhtari Garakani, Kamran Azma, Design: Kamran Azma, Farid Rezaei Moghaddam, Data Collection or Processing: Farid Rezaei Moghaddam, Analysis or Interpretation: Iman Mokhtari Garakani, Literature Search: Mozhgan Kamalifard, Mehdi Kouchakali, Writing: Iman Mokhtari Garakani.

Conflict of Interest: No conflict of interest was declared by the authors.

Financial Disclosure: The authors declared that this study received no financial support.

\section{References}

1. WHO Scientific Group on the Prevention and Management of Osteoporosis 2000: Geneva, Switzerland: Prevention and management of osteoporosis: report of a WHO scientific group; 2003.

2. Rosen CJ. Clinical practice. Postmenopausal osteoporosis. N Engl J Med 2005;353:595-603.

3. Blake GM, Fogelman I. The role of DXA bone density scans in the diagnosis and treatment of osteoporosis. Postgrad Med J 2007;83:509-17.

4. Brauer CA, Coca-Perraillon M, Cutler DM, Rosen AB. Incidence and mortality of hip fractures in the United States. JAMA 2009;302:1573-9.

5. Roche JJ, Wenn RT, Sahota O, Moran CG. Effect of comorbidities and postoperative complications on mortality after hip fracture in elderly people: prospective observational cohort study. BMJ 2005;331:1374.

6. Bentler SE, Liu L, Obrizan M, Cook EA, Wright KB, Geweke JF, et al. The aftermath of hip fracture: discharge placement, functional status change, and mortality. Am J Epidemiol 2009;170:1290-9.

7. Phy MP, Vanness DJ, Melton LJ, Long KH, Schleck CD, Larson DR, et al. Effects of a hospitalist model on elderly patients with hip fracture. Arch Intern Med 2005;165:796-801.

8. Vogel JM, Wasnich RD, Ross PD. The clinical relevance of calcaneus bone mineral measurements: a review. Bone Miner 1988;5:35-58

9. Melton LJ, Atkinson EJ, O'Fallon WM, Wahner HW, Riggs BL. Long-term fracture prediction by bone mineral assessed at different skeletal sites. J Bone Miner Res 1993;8:1227-33.

10. Gluer CC, Wu CY, Jergas M, Goldstein SA, Genant HK. Three quantitative ultrasound parameters reflect bone structure. Calcif Tissue Int 1994;55:46-52.

11. Kullenberg R. Reference database for dual X-ray and laser Calscan bone densitometer. J Clin Densitom 2003;6:367-72.

12. Costa AL, da Silva MA, Brito LM, Nascimento AC, do Carmo Lacerda Barbosa M, Batista JE, et al. Osteoporosis in primary care: an opportunity to approach risk factors. Rev Bras Reumatol Engl Ed 2016;56:111-6.

13. Schurer C, Wallaschofski $H$, Nauck M, Volzke H, Schober HC, Hannemann A. Fracture Risk and Risk Factors for Osteoporosis. Dtsch Arztebl Int 2015;112:365-71. 
14. Marshall D, Johnell O, Wedel H. Meta-analysis of how well measures of bone mineral density predict occurrence of osteoporotic fractures. BMJ 1996;312:1254-9.

15. Forogh B, Ghasemzadeh A, Salimzadeh A. Comparison of Bone Mineral Density Measured by Dual X-ray, Axial Dual-energy Photon X-ray Absorptiometry and Laser Absorptiometry of Calcaneus. Iran J Med Sci 2005;30:34-7.

16. Salimzadeh A, Forough B, Olia B SS, Alishiri GH, Ghasemzadeh A. The cut-off point of dual energy $X$ - ray and laser $(D X L)$ of calcaneus osteoporosis diagnosis in postmenopausal women. J Radiat Res 2005;3:69-72.

17. Yung PS, Lai YM, Tung PY, Tsui HT, Wong CK, Hung VW, et al. Effects of weight bearing and non-weight bearing exercises on bone properties using calcaneal quantitative ultrasound. $\mathrm{Br}$ J Sports Med 2005;39:547-51.

18. Pettersson U, Nilsson M, Sundh V, Mellstrom D, Lorentzon M. Physical activity is the strongest predictor of calcaneal peak bone mass in young Swedish men. Osteoporos Int 2010;21:447-55.
19. Nilsson $M$, Ohlsson $C$, Eriksson AL, Frandin $K$, Karlsson $M$, Ljunggren $\mathrm{O}$, et al. Competitive physical activity early in life is associated with bone mineral density in elderly Swedish men. Osteoporos Int 2008;19:1557-66.

20. Nilsson M, Sundh D, Ohlsson C, Karlsson M, Mellstrom D, Lorentzon $\mathrm{M}$. Exercise during growth and young adulthood is independently associated with cortical bone size and strength in old Swedish men. J Bone Miner Res 2014;29:1795-804.

21. Nilsson $M$, Ohlsson C, Oden A, Mellstrom D, Lorentzon M. Increased physical activity is associated with enhanced development of peak bone mass in men: a five-year longitudinal study. J Bone Miner Res 2012;27:1206-14.

22. Ruffing JA, Cosman F, Zion M, Tendy S, Garrett P, Lindsay R, et al. Determinants of bone mass and bone size in a large cohort of physically active young adult men. Nutr Metab (Lond) 2006:3:14.

23. Liberato SC, Bressan J, Hills AP. The role of physical activity and diet on bone mineral indices in young men: a cross-sectional study. J Int Soc Sports Nutr 2013;10:43. 